\title{
The influence of iron compounds in the sulfuric acid catalyst on the $\mathrm{SO}_{2}$ oxidation process
}

\author{
Marcin Grobela, Piotr Grzesiak \\ Institute of Plant Protection, Sulfuric Acid Department, ul. Miczurina 20, 60-318 Poznań, Poland, \\ e-mail: P.Grzesiak@ior.poznan.pl
}

\begin{abstract}
The catalytic oxidation process of $\mathrm{SO}_{2}$ to $\mathrm{SO}_{3}$ is the main stage of sulfuric (VI) acid production. The process run could be disordered by reason of the increased inactivation of sulfuric acid catalyst during $\mathrm{SO}_{2}$ oxidation process. This paper includes the influence study of the iron quantity and forms, which is introduced into the catalyst active phase, on the reaction rate of the $\mathrm{SO}_{2}$ oxidation process.
\end{abstract}

Keywords: catalyst active phase, reaction rate, inactivation.

\section{INTRODUCTION}

The sulfuric acid catalyst is widely used in sulfuric acid plants in order to promote the oxidation process of $\mathrm{SO}_{2}$ to $\mathrm{SO}_{3} . \mathrm{SO}_{2}$ oxidation process in sulfuric (VI) acid plants is generally taken in the multi-plate converter. The gas is cooled to proper temperature after catalyst bed passage because of high thermal effect and it is directed to the next catalyst bed.

Some sodium and cesium compounds are added as promoters into the catalyst in order to increase the reaction rate of $\mathrm{SO}_{2}$ oxidation. The addition of sodium promoter is applied in such catalysts that are assigned for the running under $\mathrm{SO}_{3}$ partial increased pressure, while the addition of cesium compounds decreases the temperature of catalyst ignition and improves catalytic properties at low temperatures up to $420^{\circ} \mathrm{C}$.

The catalyst, which is operated under industrial conditions, is inactivated after catalytic poison that is incorporated into the active phase.

Depending on the form and catalytic process conditions, the same substance in the active phase could work as a promoter or a catalytic poison. Such substances are represented by iron compounds. The presence of iron oxide in the catalyst active phase promotes $\mathrm{SO}_{2}$ oxidation over $600^{\circ} \mathrm{C}$, while iron sulfate contributes to the increased catalytic inactivation and it can sometimes even cause the physical destruction of granules.

\section{THE SOURCES OF IRON COMPOUNDS IN SULFURIC ACID SYSTEMS}

Regardless of the type of the system, the process gas, which is directed into the converter of sulfuric acid plants, should be free from dangerous impurities. One of the impurities, whose total removal from the production system is impossible, is iron compounds process (oxides) and corrosive (sulfates) occurring. Such compounds get to the converter and cause the catalyst inactivation ${ }^{\mathbf{1}, 2}$. Under some particular conditions, iron and active components can form chemical compounds that lead to the loss of the homogeneity of the active alloy. It leads to the superficial salting out of the active components that initially limits only mass and heat exchange, but later on it causes the changes of the porous catalyst surface, increased inactivation and the decreased mechanical strength of the catalysts as an effect of iron incorporation into the lattice of the catalyst active system ${ }^{3,4}$.
In sulfuric systems, the process gas is generated through sulfur combustion in the free air. The air, which is used in the sulfur combustion process, is purified in the drying tower. When the tower doesn't work properly, the air contains moisture that causes corrosion of the installation and gas pipeline in the production system. The moisture could also come from a leak of the boiler part of the furnace. As a result of that iron sulfates are present in the gas that is directed into the first plate of the converter.

In metallurgical systems, which process the gas from roasting of non-ferrous ores, the process gas is purified from contaminations and then directed into a drying tower. Since the drying tower works under more difficult conditions compared with the sulfuric acid systems, the moisture contents in the gas after that tower is higher, which leads to an increased corrosion in the process system before the converter. Iron sulfates and oxides are directed into the converter.

Another source of iron compounds could be connected with the multi-step absorption tower. As a result of low $\mathrm{SO}_{3}$ absorption effectiveness and excessive rising of drops and sulfuric acid fog, gas after the absorption tower could include high contents of sulfuric (VI) acid, which causes both the corrosion of a process system regardless of the system type and the presence of iron compounds and sulfuric acid at the second level of contacting. Sulfuric (VI) acid that condenses in catalyst pores leads to its physical destruction.

The obligation of the spent catalyst utilization creates a danger of its reutilization in the production of new catalysts, which produces another source of iron compounds in the active phase of catalysts ${ }^{5,6}$.

\section{EXPERIMENT METHODOLOGY}

The main purpose of the studies was the estimation of a dependence of $\mathrm{SO}_{2}$ to $\mathrm{SO}_{3}$ oxidation reaction rate on the temperature at sulfuric acid catalysts that include iron compounds in the active phase in different quantity and forms during its laboratory preparation. Cylindrical samples - diameter $\phi 6 \mathrm{~mm}$ - were prepared by the dry method on the foundation of natural silica carrier. The reference catalyst - without iron impurity (sample „0"), samples with different iron forms (series I, II and III) and different quantity of each form (samples I- $1 \div$ I-3; II$1 \div$ II-3; III-1 $\div$ III-3) were prepared - Table 1 . 
Table 1. The chemical constitution of the produced catalyst samples

\begin{tabular}{|c|c|c|c|c|c|}
\hline \multirow{3}{*}{ Series } & \multirow{2}{*}{ Sample } & \multicolumn{3}{|c|}{ Contents, \% } & \multirow{2}{*}{$\begin{array}{c}\text { Molar ratio } \\
\mathrm{K}_{2} \mathrm{O} / \mathrm{N}_{2} \mathrm{O}_{5}\end{array}$} \\
\hline & & $\mathrm{V}_{2} \mathrm{O}_{5}$ & $\mathrm{~K}_{2} \mathrm{O}$ & $\mathrm{Fe}_{2} \mathrm{O}_{3}$ & \\
\hline & 0 & 6.80 & 10.50 & 0.20 & 2.99 \\
\hline \multirow{3}{*}{$\mathrm{Ie}_{2} \mathrm{O}_{3}$} & 1 & 6.82 & 10.70 & 1.78 & 3.03 \\
\hline & 2 & 6.84 & 10.90 & 4.19 & 3.08 \\
\hline & 3 & 6.85 & 11.00 & 6.90 & 3.10 \\
\hline \multirow{3}{*}{$\begin{array}{l}\mathrm{II} \\
\mathrm{Fe}_{2}\left(\mathrm{SO}_{4}\right)_{3}\end{array}$} & 1 & 6.75 & 10.60 & 1.30 & 3.03 \\
\hline & 2 & 6.90 & 11.40 & 3.52 & 3.05 \\
\hline & 3 & 6.88 & 10.70 & 6.92 & 3.01 \\
\hline \multirow{3}{*}{$\begin{array}{l}\text { III } \\
\text { spent } \\
\text { catalyst }\end{array}$} & 1 & 6.65 & 10.20 & 2.50 & 3.06 \\
\hline & 2 & 6.85 & 11.20 & 3.54 & 3.27 \\
\hline & 3 & 6.86 & 10.90 & 6.88 & 3.17 \\
\hline
\end{tabular}

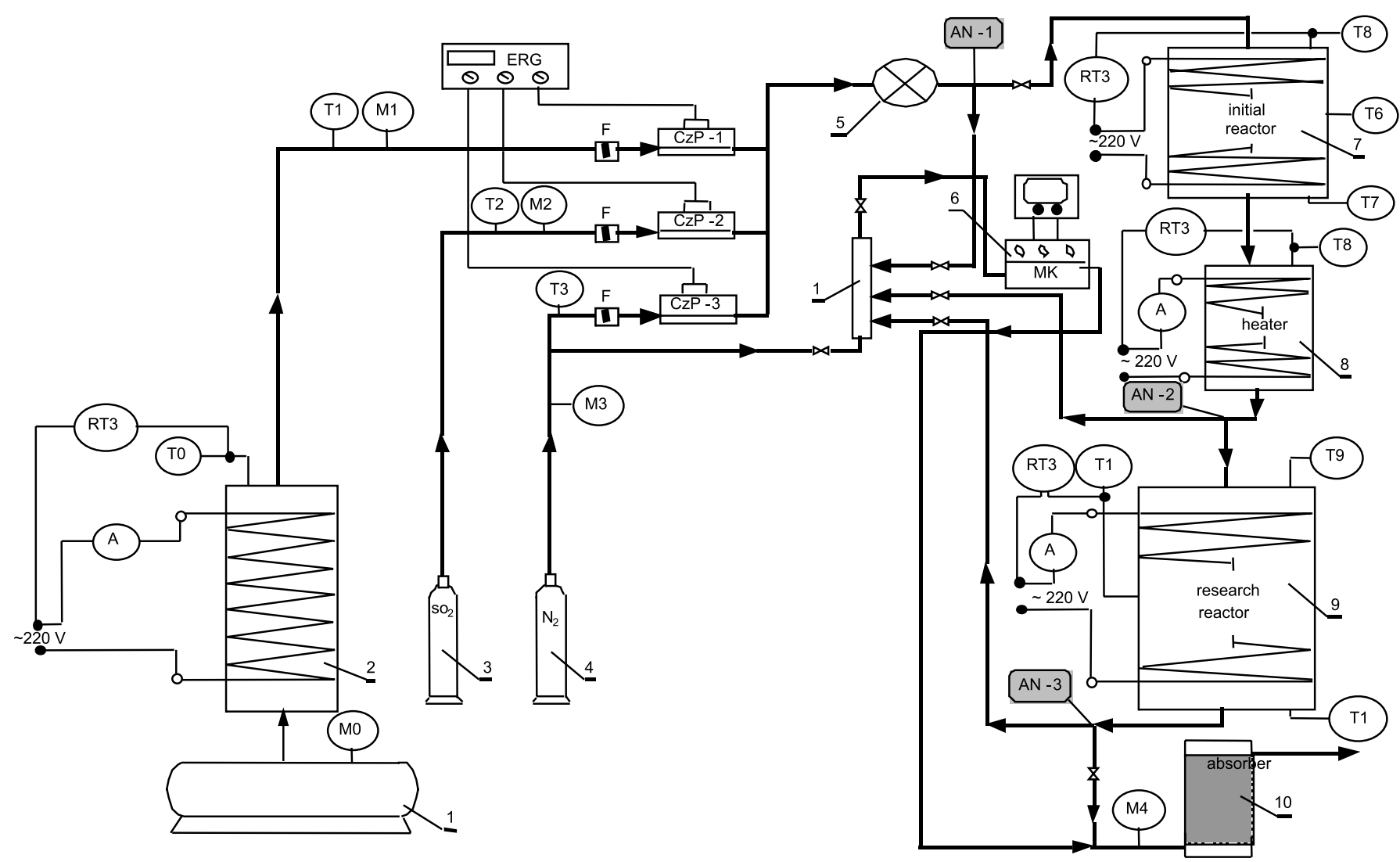

Figure 1. The apparatus scheme for the kinetics study of $\mathrm{SO}_{2}$ to $\mathrm{SO}_{3}$ oxidation process.

ERG - the electronic flow controller, RT - temperature controller, $\mathrm{T}$ - temperature measurement, $\mathrm{M}$ - manometer, $\mathrm{CzP}$ - the flow sensor, AN - the sampling point of the analyzed gas, F - filter, gas drier, 1 - air compressor, 2 - air drier, 3, 4 - gas cylinders, 5 - gas mixer, 6 - the electrochemical analyzer of the gas contents with the monitor (MK), 7 - initial reactor, 8 - gas heater, 9 - research reactor, $10-\mathrm{SO}_{2}$ and $\mathrm{SO}_{3}$ absorber, 11 - analytic collector

Prepared catalysts samples were subject to a drying process at $150^{\circ} \mathrm{C}$ temperature for $4 \mathrm{~h}$ and preliminary chemical formation at $420^{\circ} \mathrm{C}$ for $2 \mathrm{~h}$ by gas mixture: $8 \%$ $\mathrm{SO}_{2}, 13 \% \mathrm{O}_{2}$ and $79 \% \mathrm{~N}_{2}{ }^{7}$. During chemical shaping, the elements of the active phase are generated through the influence of the gaseous $\mathrm{SO}_{2}$ that comes from the combustion of sulfur in crude vanadium mass, while all processes in granules are identical to the ones in the initial period of the catalyst work-time in the converter.

In all samples of the catalysts, vanadium $\left(\mathrm{V}_{2} \mathrm{O}_{5}\right)$, potassium $\left(\mathrm{K}_{2} \mathrm{O}\right)$ and iron $\left(\mathrm{Fe}_{2} \mathrm{O}_{3}\right)$ contents were determined ${ }^{7}$ - Table 1. The catalytic properties of the prepared samples were estimated. The catalytic activity is estimated by the actual $\mathrm{SO}_{2}$ to $\mathrm{SO}_{3}$ oxidation reaction rate that is determined in the temperatures of the catalyst work-time under industrial conditions, that is from $400 \div 600^{\circ} \mathrm{C}$. The kinetics study of $\mathrm{SO}_{2}$ oxidation process was carried out according to the standard method applied in such studies ${ }^{7}$ using a specialized apparatus that was equipped with an isothermal reactor with internal gas circulation - Figures 1,2 . The research apparatus consists of four basic elements: the dosage and the control of the reaction mixture contents, the initial reactor that is responsible for the gas mixture with the proper contents of $\mathrm{SO}_{2}, \mathrm{SO}_{3}$ and $\mathrm{O}_{2}$, the research reactor that allows studying of the catalyst granules, and the system that purifies terminal gas from sulfur. The test stand is equipped with the control-measuring apparatus, which allows to determine precisely all the parameters of the studied process.

The microcoulometric analyzer of sulfur - $\mathrm{ANSO}_{2}-$ was used for the $\mathrm{SO}_{2}$ contents analysis in the gas before and after the research reactor. The principle of the measurement was based on the automatic titration of the known volume of the gas sample that contained $\mathrm{SO}_{2}$ (free of $\mathrm{SO}_{3}$ ), by the titrated solution of iodine in KI that was stabilized by acetic acid (hydrous solution that contains: 
$\left.\mathrm{KI}-0.1 \mathrm{~mol} / \mathrm{dm}^{3}, \mathrm{CH}_{3} \mathrm{COOH}-0.04 \%\right)$. The microcoulometric chamber includes four electrodes: indicator one of potentiometric circuit - OH-936P (iodine concentration detection), reference one of cell cycle $\mathrm{OH}-9327$, the anode of the current cycle OH-9327 (iodine generation) and the cathode of the current cycle OH-9377 (iodine generation). The $\mathrm{SO}_{2}$ contents is determined by the integration method of the current that is necessary for the spent iodine recovery. The determination accuracy of $\mathrm{SO}_{2}$ concentration was $0.001 \%(\mathrm{v} / \mathrm{v}) \mathrm{SO}_{2}$. The electrochemical analyzer of $\mathrm{SO}_{2}$ cooperates with the electronic analyzer of oxygen - OM200, which allows the percentage estimation of $\mathrm{O}_{2}$ contents in the reaction mixture. The determination accuracy of $\mathrm{O}_{2}$ concentration was $0.001 \%(\mathrm{v} / \mathrm{v}) \mathrm{O}_{2}$. The manometer is installed in the gas cycle of the research reactor, which allows the pressure measurement of the reaction mixture.

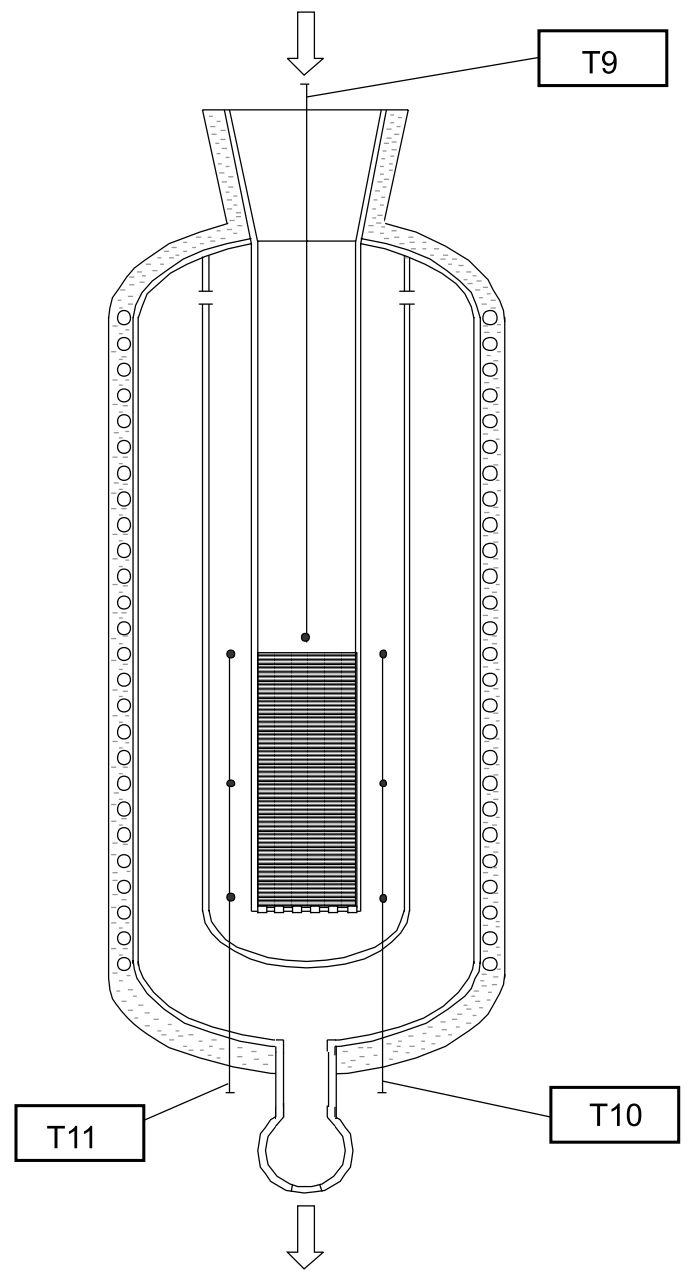

Figure 2. The research reactor scheme. T9, 10, 11 - thermocouples

The special design of the research reactor, which allows the examination of the whole catalyst granules, has been used for the kinetics study. The reactor is made of the silica glass, while the sample of the examined catalyst is situated centrally in a pipe inside the reactor. The reaction gas, which is characterized by proper temperature and the chemical constitution, flows through the examined catalyst layer, and later on it flows around the pipe and stabilizes the temperature of the deposit at the whole height. The reactor includes thermocouples that measure, register and regulate the temperature inside the gas cycle. The temperature measurement, the registration and the regulation are run directly over the catalyst layer, while the temperature measurement is done under it.

In all the studies the catalysts samples weighed $40.0 \pm$ $0.1 \mathrm{~g}$. The value of the flow of each gas mixture (air, nitrogen and $\mathrm{SO}_{2}$ ) components has been determined. In the heater (8), the gas was heated up to $400^{\circ} \mathrm{C}$ (the thermocouple indication T9) - Figure 1. After the stabilization of the conditions, $\mathrm{SO}_{2}$ concentration measurement in the proper measurement points was run. Another measurement series of $\mathrm{SO}_{2}$ concentration in the gas were run in $420^{\circ} \mathrm{C}$, and the next ones at higher temperatures $\left(20^{\circ} \mathrm{C}\right.$ higher each time) in the temperature range from 400 to $600^{\circ} \mathrm{C}$. The kinetics parameters of the studied process were determined for the gas that consisted of: $8 \% \mathrm{SO}_{2}$, $13 \% \mathrm{O}_{2}$ and $79 \% \mathrm{~N}_{2}$ with the linear speed of the gas flow $0.35 \mathrm{Nm} / \mathrm{s}$ that was fixed for an empty reactor section. $\mathrm{SO}_{2}$ to $\mathrm{SO}_{3}$ conversion for a given temperature $\left(\mathrm{x}_{\mathrm{t}}\right)$ was determined from $\mathrm{SO}_{2}$ concentration in the gas before $\left(\mathrm{c}_{2}\right)$ and after the research reactor $\left(c_{3}\right)$ using formula 1 :

$x_{t}=\frac{\left(c_{2}-c_{3}\right) * 10^{4}}{c_{2} *\left(100-1,5 * c_{3}\right)}$

where: $\mathrm{x}_{\mathrm{t}}-\mathrm{SO}_{2}$ conversion in the measurement temperature $\mathrm{t}(\%), \mathrm{c}_{2}-\mathrm{SO}_{2}$ concentration before the research reactor in the analytic point $\mathrm{AN} 2(\%), \mathrm{c}_{3}-\mathrm{SO}_{2}$ concentration after the research reactor in the analytic point AN3 (\%) - Figure 1

The actual $\mathrm{SO}_{2}$ oxidation reaction rate (r) was calculated using formula 2:

$r_{t}=\frac{V_{S O_{2}} \times x_{t}}{21,89 \times m_{k}}$

where: $\mathrm{r}$ - the actual reaction rate in the measurement point $\mathrm{t}\left(\mathrm{mol} \mathrm{SO}_{3} / \mathrm{g}_{\mathrm{k}} \mathrm{xh}\right), \mathrm{V}_{\mathrm{SO} 2}-\mathrm{SO}_{2}$ flow intensity $\left(\mathrm{Ndm}^{3} / \mathrm{h}\right), \mathrm{x}_{\mathrm{t}}-\mathrm{SO}_{2}$ conversion in the measurement point $\mathrm{t}(\%), \mathrm{m}_{\mathrm{k}}$ - catalyst mass $(\mathrm{g}), 21.89-\mathrm{SO}_{3}$ molar volume, $\mathrm{Ndm}^{3} / \mathrm{mol}$.

Using the actual $\mathrm{SO}_{2}$ oxidation reaction rates for the catalysts without $\left(r_{\mathrm{o}}\right)$ and with iron addition $\left(\mathrm{r}_{\mathrm{i}}\right)$, the reaction rate decrease was determined using formula 3 :

$\eta=\frac{r_{i}}{r_{o}}$

where: $\eta$ - the decrease of the actual reaction rate $(\% \mathrm{n} / \mathrm{n}), \mathrm{r}_{\mathrm{i}}$ - the actual reaction rate for the catalyst without iron addition, $r_{o}$ - the actual reaction rate for the catalyst with iron addition.

\section{RESULTS AND DISCUSSION}

Sulfuric acid catalysts, which include different contents of iron that is incorporated into the active phase in diversified forms, and the reference sample (sample „0”) without iron, which is additionally introduced during sample preparation, were generated - Table 1 . The influence of iron was estimated by the measurement of the actual $\mathrm{SO}_{2}$ to $\mathrm{SO}_{3}$ oxidation reaction rate - Table 2 . The quantitative measure of that influence is the decrease of the actual reaction rate that allows the estimation of iron quantity and form influence in the active phase of catalysts on its catalytic properties.

All experiments demonstrated the decrease of $\mathrm{SO}_{2}$ oxidation reaction rate when iron contents (oxide form) increased, but the highest one was observed for temperature 
Table 2. The actual reaction rates of $\mathrm{SO}_{2}$ oxidation $\mathrm{r}^{*} 10^{-4}\left(\mathrm{~mol} \mathrm{SO}_{3} / \mathrm{h}^{*} \mathrm{~g}\right)$ of the catalysts studied

\begin{tabular}{|c|c|c|c|c|c|c|c|c|c|c|}
\hline \multirow{4}{*}{$\begin{array}{l}\text { Temp. } \\
{ }^{\circ} \mathrm{C}\end{array}$} & \multicolumn{10}{|c|}{$\mathrm{SO}_{2}$ oxidation reaction rate, $\mathrm{r}^{*} 10^{-4}\left(\mathrm{~mol} \mathrm{SO}_{3} / \mathrm{h}^{*} \mathrm{~g}\right)$} \\
\hline & \multicolumn{10}{|c|}{ The form and the contents of the introduced iron, $\%$} \\
\hline & „0" & \multicolumn{3}{|c|}{ oxides } & \multicolumn{3}{|c|}{ sulfates } & \multicolumn{3}{|c|}{ spent catalyst } \\
\hline & 0.2 & 1.78 & 4.19 & 6.9 & 1.3 & 3.52 & 6.92 & 2.5 & 3.54 & 6.88 \\
\hline 420 & 72 & 66 & 58 & 51 & 59 & 52 & 48 & 46 & 29 & 24 \\
\hline 440 & 128 & 118 & 116 & 106 & 117 & 108 & 98 & 98 & 62 & 52 \\
\hline 460 & 240 & 233 & 230 & 225 & 226 & 220 & 214 & 168 & 118 & 98 \\
\hline 480 & 350 & 338 & 332 & 324 & 336 & 320 & 306 & 264 & 189 & 179 \\
\hline 500 & 412 & 411 & 402 & 383 & 391 & 382 & 368 & 336 & 264 & 248 \\
\hline 520 & 418 & 418 & 414 & 403 & 404 & 398 & 384 & 358 & 298 & 286 \\
\hline 540 & 416 & 415 & 413 & 402 & 402 & 394 & 380 & 356 & 296 & 284 \\
\hline 560 & 412 & 410 & 408 & 400 & 400 & 390 & 374 & 354 & 294 & 281 \\
\hline 580 & 410 & 408 & 406 & 398 & 398 & 384 & 372 & 351 & 288 & 276 \\
\hline 600 & 408 & 406 & 404 & 396 & 396 & 380 & 370 & 348 & 284 & 272 \\
\hline
\end{tabular}

$420^{\circ} \mathrm{C}-$ Figure 3 . Figure 3 presents the relations at standard temperatures $-420^{\circ} \mathrm{C}$ and $480^{\circ} \mathrm{C}$. The actual $\mathrm{SO}_{2}$ oxidation reaction rate at the catalyst that contained $1.78 \%$ $\mathrm{Fe}_{2} \mathrm{O}_{3}$ was $66^{*} 10^{-4}\left(\mathrm{~mol} \mathrm{SO}{ }_{3} / \mathrm{h}^{*} \mathrm{~g}\right.$ ) in $420^{\circ} \mathrm{C}$ and $338^{*} 10^{-}$ ${ }^{4}\left(\mathrm{~mol} \mathrm{SO}{ }_{3} / h^{*} \mathrm{~g}\right)$ in $480^{\circ} \mathrm{C}$, and it was lower than the reaction rate at the catalyst without iron addition. As the iron contents increased up to $6.9 \% \mathrm{Fe}_{2} \mathrm{O}_{3}$, the reaction rate decreased to 51 and $324 * 10^{-4}\left(\mathrm{~mol} \mathrm{SO}_{3} / \mathrm{h} * \mathrm{~g}\right)$ respectively.

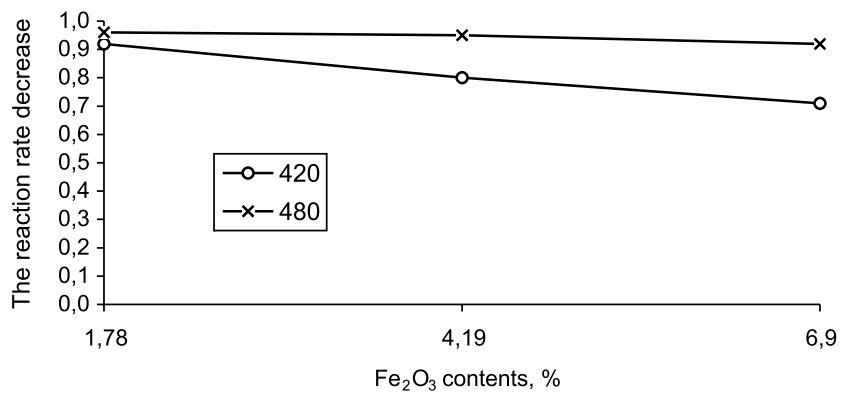

Figure 3. The relation between $\mathrm{SO}_{2}$ oxidation reaction rate and iron contents (oxide form) at standard temperatures

Similar relations are observed for the activity of the generated catalysts with iron contents as sulfates - Figure 4.

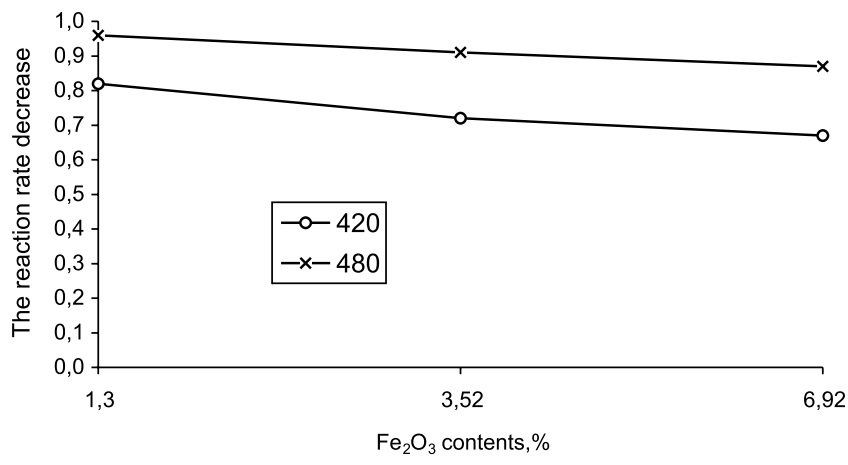

Figure 4. The relation between $\mathrm{SO}_{2}$ oxidation reaction rate and iron contents (sulfate form) at standard temperatures

The studies demonstrated that the highest decrease of $\mathrm{SO}_{2}$ oxidation reaction rate was observed for the catalyst with iron addition, which was incorporated with the spent catalyst - Figure 5. The actual $\mathrm{SO}_{2}$ oxidation rate was $46^{*} 10^{-4}\left(\mathrm{~mol} \mathrm{SO}_{3} / \mathrm{h}^{*} \mathrm{~g}\right)$ in $420^{\circ} \mathrm{C}$ and $264^{*} 10^{-4}\left(\mathrm{~mol} \mathrm{SO}_{3} /\right.$ $\mathrm{h}^{*} \mathrm{~g}$ ) in $480^{\circ} \mathrm{C}$ with $2.5 \% \mathrm{Fe}_{2} \mathrm{O}$ contents, while with $6.9 \%$ $\mathrm{Fe}_{2} \mathrm{O}_{3}$ contents it decreased to 24 and $179^{*} 10^{-4}$ (mol $\left.\mathrm{SO}_{3} / \mathrm{h} * \mathrm{~g}\right)$.

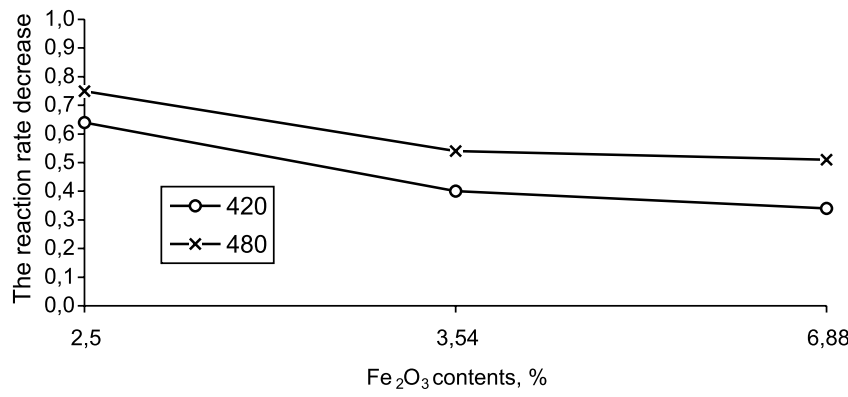

Figure 5. The relation between $\mathrm{SO}_{2}$ oxidation reaction rate and iron contents (spent catalysts) at standard temperatures

The studies demonstrated the influence of the incorporated iron form on the decrease of $\mathrm{SO}_{2}$ oxidation reaction rate. The relatively small changes of the reaction rate were observed for iron oxide and sulfate. The higher decrease of the reaction rate was observed for the catalysts that contained iron from the spent sulfuric acid catalyst Figure 6.

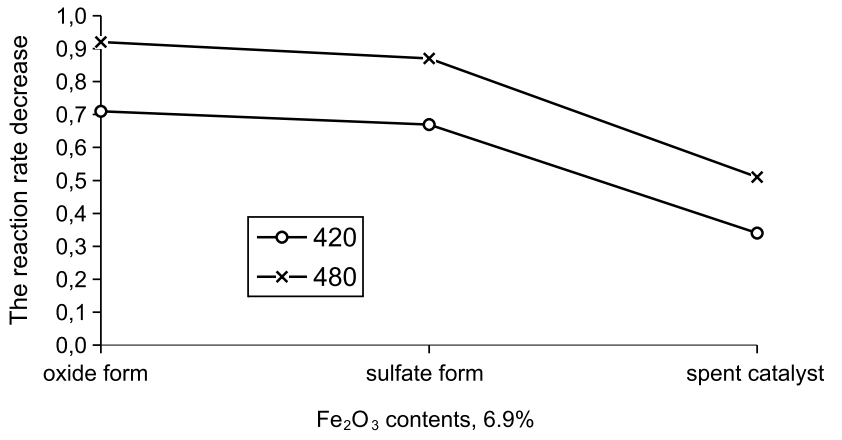

Figure 6. The relation between $\mathrm{SO}_{2}$ oxidation reaction rate and iron form at standard temperatures

\section{CONCLUSIONS}

The carried studies of the iron influence in sulfuric acid catalysts on the catalytic activity lead to several conclusions:

- The presence of iron in the active phase causes the decrease of $\mathrm{SO}_{2}$ oxidation reaction rate,

- The reaction rate decreases as the iron contents increases, regardless of the introduced iron form,

- The reaction rate decrease depends on the temperature of the catalyst work and it is higher at lower temperatures regardless of the quantity and forms of the introduced iron,

- The lowest decrease of reaction rate is observed for iron oxide in the catalyst, 
- The highest decrease of the reaction rate is observed for the catalysts that are prepared with the spent sulfuric acid catalyst addition.

\section{LITERATURE CITED}

(1) Grzesiak P.: Kwas Siarkowy. Tom 4. Katalizatory wanadowe do utleniania $\mathrm{SO}_{2}$, IOR Poznan 2005, ISBN 8389867-50-8.

(2) Grzesiak P.: Kwas siarkowy. Tom 1. Metody i technologie produkcji kwasu siarkowego. IOR Poznan 2002, ISBN83-916204-2-5.

(3) Grzesiak P., Gapińska T., Schroeder G., Domka F.: Chemik 2002, 9, 258.

(4) Grzesiak P., Gapińska T., Hłyń T.: Kwas siarkowy, wczoraj - dziś - jutro, IOR Poznań 2000, ISBN 83-913860-0-7.

(5) Best Available Techniques for Pollution Prevention and Control in the European Sulphuric Acid and Fertilizer Industries, Booklet No. 3 of 8, Production of Sulphuric Acid, ESA/EFMA 2000.

(6) Grzesiak P.: Kwas Siarkowy. Tom 2. Najlepsze dostępne techniki BAT w produkcji kwasu siarkowego, IOR Poznań, 2004 ISBN 83-916204-9-2.

(7) Grzesiak P., Schroeder G.: Kwas siarkowy (VI). Technologia, ekologia, analityka, ekonomia, UAM Poznan 1999, ISBN 83-904685-6-5. 